\title{
Analisis Politik Hukum Undang-Undang Nomor 23 Tahun 2019 Tentang Pengelolaan Sumber Daya Nasional Untuk Pertahanan Negara
}

\author{
Dede Anggara Saputra \\ Magister Ilmu Hukum Universitas Islam Indonesia Yogyakarta Indonesia \\ Jln. Cik Di Tiro No. 1, Yogyakarta 55223 Indonesia \\ 19912008@students.uii.ac.id
}

\begin{abstract}
This study aims to analyze the legal politics of Law Number 23 of 2019 on Management of National Resources for National Defense. The legal issues presented in this study are the political direction of Law Number 23 of 2019 on the Management of National Resources for National Defense and its implications for the people. This is a normative legal research, which the results conclude that the birth of the a quo Law is motivated by a situation to strengthen the national defense in the face of threats through the universal people's defense system. The legal political direction of the a quo Law is to realize the upholding of state sovereignty, maintaining territorial integrity, and the safety of the entire nation from all forms of threats. In addition, a number of principles listed as the basis in the a quo Law are quite manifest in several articles. However, these principles are then reduced by the tendency of the material content of the a quo Law which has the nuances of violating human rights, overcriminalization, being less accommodating to current threat conditions, as well as creating the potential for misuse in its funding.
\end{abstract}

Key Words: Legal policy; national defence; national resources

\begin{abstract}
Abstrak
Penelitian ini bertujuan untuk menganalisis politik hukum Undang-Undang Nomor 23 Tahun 2019 tentang Pengelolaan Sumber Daya Nasional untuk Pertahanan Negara. Permasalahan hukum yang dianalissi dalam penelitian ini adalah arah politik hukum Undang-Undang Nomor 23 tahun 2019 tentang Pengelolaan Sumber Daya Nasional untuk Pertahanan Negara dan implikasinya terhadap rakyat. Penelitian ini merupakan penelitian hukum normatif. Hasil penelitian ini menyimpulkan bahwa lahirnya Undang-Undang a quo dilatarbelakangi oleh suatu keadaan untuk memperkuat pertahanan negara dalam menghadapi ancaman melalui sistem pertahanan rakyat semesta. Arah politik hukum Undang-Undang a quo ialah mewujudkan tegaknya kedaulatan negara, terjaganya keutuhan wilayah, dan keselamatan segenap bangsa dari segala bentuk ancaman. Selain itu, sejumlah asas yang tercantum sebagai dasar dalam UU a quo cukup termanifestasi dalam beberapa pasal. Namun demikian, asas-asas ini kemudian tereduksi oleh kecenderungan materi muatan Undang-Undang a quo yang bernuansa melanggar hak asasi manusia, overkriminalisasi, kurang akomodatif terhadap kondisi ancaman kekinian, serta menimbulkan potensi penyalahgunaan dalam pendanaannya.
\end{abstract}

Kata-kata Kunci: Politik hukum; pertahanan negara; sumber daya nasional 


\section{Pendahuluan}

Pembukaan Undang-Undang Dasar Negara Republik Indonesia Tahun 1945 memuat salah satu tujuan dibentuknya Pemerintahan Negara Indoensia yakni untuk melindungi segenap bangsa Indonesia dan seluruh tumpah darah Indonesia. Pertahanan negara merupakan faktor yang sangat hakiki dalam menjamin kelangsungan hidup suatu negara. Eksistensi sebuah negara sangat bergantung pada kemampuan bangsa mempertahankan diri dari setiap ancaman.

Secara geografis, Indonesia merupakan gerbang utama bagi kawasan Asia Pasifik dimana tingkat keamanan kawasan tersebut akhir-akhir ini cenderung meningkat, yaitu terjadinya saling klaim wilayah teritori antara beberapa negara sehingga memperbesar konsentrasi pengarahan militer di kawasan ini. Terkait hal ini, sengketa teritorial yang melibatkan negara Tiongkok, Vietnam, Filiphina, Malaysia, Taiwan, dan Brunei bukan tidak mungkin mengarah ke kawasan Natuna yang merupakan wilayah kedaulatan Indonesia. Tidak mengherankan jika sengketa di kawasan tersebut pada akhirnya berkembang menjadi ajang persaingan kekuatan militer dunia ketika negara adidaya, seperti Amerika Serikat, ikut unjuk kekuatan dalam melindungi kepentingannya di kawasan tersebut. Kebangkitan Tiongkok dan hegemoni Amerika Serikat, khususnya di Kawasan Asia Pasifik, juga menghadirkan kondisi baru pada pergerakan dunia saat ini. Kebangkitan Tiongkok memberikan sinyal akan (atau sedang) adanya perubahan dalam keseimbangan kekuatan baru dalam hubungan internasional. ${ }^{1}$

Dinamika ancaman pertahanan Indonesia ke depan ditunjukkan dengan cepatnya pertumbuhan persenjataan dan juga meningkatnya ancaman perang menjadi perang terbuka. ${ }^{2}$ Oleh karena itu, Indonesia perlu menata kembali kekuatan pertahanannya untuk menghadapi perkembangan ancaman yang makin beragam. Permasalahan ini tidak dapat ditangani dari aspek kekuatan utama militer saja mengingat ada 3 pilar yang harus saling keterkaitan dalam rangka membangun ketahanan nasional, yaitu pemerintahan, militer, dan rakyat. Ketiga pilar tersebut dijalin dalam simpul untuk memperkuat negara sementara pemerintahan dengan rakyat diikat dengan simpul ideologi, dan tentara dengan rakyat diikat dengan simpul sejarah hubungan emosional kemanunggalan tentara-rakyat. Selain itu, pemerintah dengan rakyat diikat dengan simpul regulasi untuk membangun landasan legal formal yang mengatur tugas dan fungsi tentara dalam sistem bernegara.

${ }^{1}$ Hendra Maujana Saragih, "Diplomasi Pertahanan Indonesia Dalam Konflik Laut China Selatan”, Jurnal Ilmu Politik dan Komunikasi, Vol. 7 No. 1, Juni 2018, hlm. 49.

2 Dewie Mardhani et.al., "Keamanan dan Pertahanan Dalam Studi Ketahanan Nasional Guna Mewujudkan Sistem Keamanan Nasional”, Jurnal Pertahanan \& Bela Negara, Vol. 10 No. 3, Desemeber 2020, hlm. 288. 
Peperangan di era global merupakan hasil metamorposis dari perang tradisional menjadi bentuk perang modern yang lebih rumit dan spesifik. Peperangan tidak hanya sebatas perang fisik dengan pengarahan kekuatan militer namun peperangan dirancang menggunakan berbagai cara dan taktik dalam menghancurkan lawan. Keefektifan menjadi salah satu ukuran, sehingga negara harus pandai menata dan mengelola seluruh sumber daya nasional yang dimiliki untuk menjadi kekuatan yang potensial bagi kekuatan pertahanan sebuah negara.

Sistem tata kelola sumber daya nasional untuk pertahanan negara merupakan langkah strategis agar sistem pertahanan semesta dapat diaplikasikan serta terbangun daya saing sebagai bangsa. Jadi, pengaturan pengelolaan sumber daya nasional untuk pertahanan negara sangat penting dan strategis. Apabila negara membutuhkan sumber daya nasional untuk menunjang kepentingan negara, telah tersedia koridor hukum untuk penggunaan sumber daya nasional yang tetap berlandaskan kepada demokrasi, penghormatan terhadap hak asasi manusia, dan supremasi sipil.

Perkembangan teknologi informasi dan telekomunikasi, serta teknologi transportasi mempercepat arus informasi, arus finansial global, dan mobilitas manusia. Berbagai fenomena perubahan tersebut bukan tidak mungkin membawa akses yang potensial menjadi ancaman bagi suatu negara. Ancaman tidak hanya dalam bentuk fisik, akan tetapi ancaman nonfisik seperti ancaman nilai-nilai kehidupan asing yang dapat menjadi alat penghancur entitas sebuah peradaban bangsa. Atas dasar gambaran dari realitas yang telah diuraikan di atas, maka dilahirkannya Undang-Undang Nomor 23 Tahun 2019 tentang Pengelolaan Sumber Daya Nasional untuk Pertahanan Negara (UU PSDN).

\section{Rumusan Masalah}

Berdasarkan pemaparan yang telah dikemukakan di atas, maka penulis mengangkat dua permasalahan sebagai berikut : pertama, bagaimana arah politik hukum Undang-Undang Nomor 23 Tahun 2019 tentang Pengelolaan Sumber Daya Nasional untuk Pertahanan Negara? Kedua, bagaimana implikasi UndangUndang Nomor 23 Tahun 2019 tentang Pengelolaan Sumber Daya Nasional untuk Pertahanan Negara terhadap rakyat?

\section{Tujuan Penelitian}

Penelitian ini bertujuan untuk mengetahui dan menganalisis, pertama, arah politik hukum Undang-Undang Nomor 23 Tahun 2019 tentang Pengelolaan Sumber Daya Nasional untuk Pertahanan Negara, dan kedua, implikasi dari 
Undang-Undang Nomor 23 Tahun 2019 tentang Pengelolaan Sumber Daya Nasional untuk Pertahanan Negara terhadap rakyat.

\section{Metode Penelitian}

Penelitian ini merupakan penelitian hukum normatif, atau juga biasa disebut dengan studi dogmatik atau penelitian doktrinal (doctrinal research). ${ }^{3}$ Adapun yang dimaksud dengan penelitian doktrinal adalah penelitian atas hukum yang dikonsepkan dan dikembangkan berdasarkan doktrin yang dianut oleh pembuat konsep dan/atau pengembangnya. ${ }^{4}$ Penelitian ini menggunakan metode penelitian bersifat deskriptif analitis, analisis data yang dipergunakan adalah pendekatan kualitatif terhadap data primer dan data sekunder. ${ }^{5}$

\section{Hasil Penelitian dan Pembahasan}

\section{Arah Politik Hukum Undang-Undang Nomor 23 Tahun 2019 tentang Pengelolaan Sumber Daya Nasional untuk Pertahanan Negara.}

Politik hukum adalah legal policy atau garis (kebijakan) resmi tentang hukum yang akan diberlakukan baik dengan hukum baru maupun dengan penggantian hukum lama, dalam rangka mencapai tujuan negara. ${ }^{6}$ Sederhananya, politik hukum merupakan pilihan politis institusi pembentuk hukum untuk memberlakukan hukum yang digunakan untuk mencapai tujuan yang dikehendaki. Studi politik hukum sekurang-kurangnya meliputi 3 hal yakni, (1) kebijakan negara (garis resmi) tentang hukum yang akan diberlakukan atau tidak diberlakukan dalam rangka mencapai tujuan negara; (2) latar belakang politik, ekonomi, sosial, budaya, atas lahirnya produk hukum; dan (3) penegakan hukum di dalam kenyataan lapangan. ${ }^{7}$

Arah politik hukum suatu undang-undang dapat diketahui dari landasan filosofis dan sasaran pengaturan sebagaimana kajian dalam naskah akademik. Adapun arah politik hukum Undang-Undang Nomor 23 Tahun 2019 tentang Pengelolaan Sumber Daya Nasional untuk Pertahanan Negara sebagaimana termaktub dalam landasan filosofis adalah bahwa pengaturan sumber daya nasional untuk pertahanan negara ini dimaksudkan sebagai upaya penting dan strategis negara dalam menata keteraturan untuk keefektifan sistem pertahanan. ${ }^{8}$

\footnotetext{
${ }^{3}$ Bambang Sungguno, Metode Penelitian Hukum, Raja Grafindo Persada, Jakarta, 2003, hlm. 42.

4 Sulistyowati Irianto dan Shidarta, Metode Penelitian Hukum: Konstelasi dan Refleksi, Cetakan Pertama, Yayasan Obor Indonesia, Jakarta, 2009, hlm. 121.

5 Zainuddin Ali, Metode Penelitian Hukum, Cetakan Kelima, Sinar Grafika, Jakarta, 2014, hlm. 107.

${ }^{6}$ Moh. Mahfud MD, Politik Hukum di Indoensia, Cetakan Ketujuh, Rajawali Pers, Jakarta, 2017, hlm 1.

${ }^{7}$ Ibid., hlm. 3-4.

8 Naskah Akademik Rancangan Undang-Undang tentang Pengelolaan Sumber Daya Nasional untuk Pertahanan Negara, https://www.bphn.go.id/data/document/na ruu tentang pengelolaan sumber daya nasional
} 
Oleh karena itu, pelibatan sumber daya nasional untuk pertahanan negara ditujukan untuk memperbesar dan memperkuat komponen utama, yakni Tentara Nasional Indonesia (TNI) yang merupakan alat negara yang menangani bidang pertahanan, dan dalam pelaksanaannya dibantu komponen lain yaitu komponen pendukung dan komponen cadangan yang berasal dari rakyat.

Sasaran penyusunan undang-undang a quo ini diantaranya yaitu, pertama, sebagai upaya pemerintah untuk menuntaskan reformasi hukum di bidang pertahanan, kedua, merupakan manifestasi dari konsep pertahanan rakyat semesta sebagai bagian dari grand strategi nasional dalam bidang pertahanan, ketiga, membangun sistem pertahanan adaptif, visioner yang memiliki daya tangkal dan disiapkan secara dini, terarah, serta berkelanjutan oleh negara untuk menghadapi ancaman, keempat, terbangunnya karakter bangsa yang secara sadar dan sukarela ikut serta dalam usaha bela negara, kelima, tertatanya wilayah pertahanan negara yang akan menjadi trigger bagi penataan sektor lainnya, yaitu menjadikan wilayah negara kesatuan Republik Indonesia menjadi satu kesatuan utuh wilayah pertahanan negara, dan terakhir, terbentuknya postur pertahanan ideal yang terdiri dari komponen utama, cadangan, dan pendukung. ${ }^{9}$

Rincian di atas kemudian diformulasikan dalam konsideran undang-undang a quo, yang salah satu diantaranya menyebutkan bahwa sistem pertahanan negara bersifat semesta yang melibatkan seluruh sumber daya nasional yang dipersiapkan secara dini oleh pemerintah dan diselenggarakan secara total, terpadu, terarah, dan berkenlanjutan untuk menegakkan kedaulatan negara, menjaga keutuhan wilayah, dan keselamatan segenap bangsa dari segala bentuk ancaman. Konsideran tersebut menggambarkan adanya keinginan untuk mewujudkan tegaknya kedaulatan negara, terjaganya keutuhan wilayah, dan keselamatan segenap bangsa dari segala bentuk ancaman. Oleh karena itu, dalam mencapai tujuan tersebut, fungsi pertahanan negara diselenggarakan dengan memanfaatkan seluruh potensi sumber daya nasional serta sarana dan prasarana nasional sebagai bagian penting dari komponen pertahanan negara sekaligus digunakan bagi kesejahteraan rakyat.

Pengelolaan sumber daya nasional untuk pertahanan negara ini bertujuan untuk mentransformasikan sumber daya nasional menjadi kekuatan pertahanan negara yang siap digunakan untuk kepentingan pertahanan negara melalui usaha bela negara, penataan komponen pendukung, dan pembentukan komponen cadangan. Atas usaha tersebut, maka salah satu hal yang diinginkan dengan

untuk pertahanan negara.pdf, hlm. 73. Retna Gumanti, "Reconceptualizing Consumer Contracts in the Philosophical Perspective of Pancasila”, 1 (1) Prophetic Law Review 37, 2019, hlm. 37-39.

${ }^{9}$ Ibid., hlm. 78. 
adanya undang-undang a quo ini kepada masyarakat ialah akan dilakukannya proses indoktrinasi visi kenegaraan yang sama, yang dimulai dari pembinaan kesadaran bela negara sebagai upaya kanalisasi potensi militansi rakyat. ${ }^{10}$

Secara umum, pembentukan Undang-Undang a quo cukup dilakukan secara terbuka, dibuktikan dengan adanya Rapat Dengar Pendapat Umum (RDPU), yang mengundang sejumlah elemen masyarakat yang berkepentingan. Pihak yang diundang dan hadir dalam RDPU antara lain pakar FISIP UI, pakar CSDS UI, Direktur Eksekutif Amnesty Internasional Indonesia, Wakil Direktur Imparsial, LHKP Muhammadiyah. ${ }^{11}$ Akan tetapi, di tengah konfigurasi politik yang demokratis, undang-undang a quo yang seharusnya dapat disusun secara lebih partisipatif dan aspiratif, namun proses pembentukan yang melibatkan publik melalui RDPU hanya dilakukan sebanyak 2 kali saja, yaitu pada RDPU Komisi 1 DPR RI dengan Asosiasi Pengusaha Indonesia (APINDO) 20 Agustus 2019, dan RDPU Komisi 1 DPR RI dengan Akademisi/LSM/Ormas 21 Agustus 2019.12

\section{Asas-Asas yang Digunakan dan Penerapannya dalam Pasal-pasal}

\section{Asas Tujuan}

Asas ini bermakna bahwa pengelolaan sumber daya nasional harus dilaksanakan secara terukur dan mengarah pada pencapaian tujuan untuk mentransformasikan sumber daya nasional menjadi kekuatan pertahanan negara. Asas ini termuat dalam dua pasal, yaitu Pasal 3, yang menyatakan bahwa pengelolaan sumber daya nasional untuk pertahanan negara bertujuan untuk mentransformasikan sumber daya manusia, sumber daya alam, dan sumber daya buatan, serta sarana dan prasarana nasional menjadi kekuatan pertahanan negara; dan Pasal 4, yang menyebutkan bahwa pengelolaan sumber daya nasional untuk pertahanan negara dipersiapkan secara dini untuk menghadapi ancaman.

\section{Asas Kesemestaan}

Asas ini mengandung makna penyelenggaraan sistem pertahahan keamanan negara harus melibatkan seluruh sumber daya nasional yang dimiliki meliputi sumber daya manusia, sumber daya alam dan buatan, serta sarana dan prasarana yang dalam pelibatannya dibagi menjadi komponen cadangan dan komponen pendukung yang dimulai dengan pembinaan kesedaran bela negara bagi seluruh rakyat. Asas kesemestaan yang dimasukkan ke dalam materi muatan Pasal 5 yang menyatakan bahwa pengelolaan sumber daya nasional untuk

\footnotetext{
${ }^{10}$ Ibid., hlm. 44.

11 Risalah Rapat Komisi I DPR RI pada Rabu, 21 Agustus 2019.

${ }^{12}$ http://www.dpr.go.id/uu/detail/id/44, Diakses pada 20 Maret 2021.
} 
pertahanan negara dilaksanakan melalui beberapa usaha, yaitu bela negara, penataan komponen pendukung, pembentukan komponen cadangan, dan penguatan komponen utama, serta mobilisasi dan demobilisasi.

\section{Asas Keuangan}

Penyelenggara negara dan seluruh rakyat Indonesia harus memiliki mental, tekad, jiwa dan semangat pengabdian, kerelaan berkorban, dan disiplin yang tinggi dengan lebih mengutamakan kepentingan bangsa dan negara di atas kepentingan pribadi dan/atau golongan yang dilaksanakan dengan penuh kejujuran, kebenaran, dan keadilan. Patriotisme yang tertanam mendarah daging merupakan sebuah soft power resource yang tidak terkelola, dibutuhkan saluran yang tepat agar berdaya guna bagi pembangunan negara. Asas ini terimplementasi dalam muatan beberapa pasal yaitu Pasal 14, Pasal 15, dan Pasal 17 ayat (2). Pasal 14 mengatur bahwa pengabdian sebagai prajurit Tentara Nasional Indonesia secara sukarela atau secara wajib dilaksanakan sesuai dengan ketentuan peraturan perundang-undangan. Pasal 15 menyebutkan bahwa setiap warga negara melaksanakan pengabdian sesuai dengan profesinya untuk kepentingan Pertahanan Negara. Sementara Pasal 17 ayat (2) menyatakan bahwa komponen pendukung merupakan salah satu wadah keikutsertaan warga negara secara sukarela dan pemanfaatan sumber daya alam, sumber daya buatan, serta sarana dan prasarana nasional dalam usaha penyelenggaraan pertahanan negara.

\section{Asas Kebersamaan dan Gotong Royong/Kolektivitas}

Makna asas ini adalah penyelenggaraan upaya pertahanan keamanan Negara adalah aspek kepentingan nasional di bidang keamanan. Setiap warga negara dalam lapisan masyarakat secara bersama-sama harus memperoleh dan menggunakan kesempatan yang sama di dalam peran sertanya membela negara. Beban besar membangun kekuatan pertahanan negara akan lebih ringan apabila ada gerakan sinergi dari seluruh komponen bangsa. Implementasi asas ini terdapat dalam beberapa pasal yaitu pertama, Pasal 5 ayat (1), sebagaimana telah disebutkan sebelumnya, kedua, Pasal 6 ayat (1), yang menyebutkan bahwa setiap warga negara berhak dan wajib ikut serta dalam usaha bela negara yang diwujudkan dalam penyelenggaraan pertahanan negara, dan ketiga, Pasal 6 ayat (2) yang mengatur bahwa keikutsertaan warga negara dalam usaha bela negara sebagaimana dimaksud pada ayat (1) diselenggarakan melalui pendidikan kewarganegaraan, pelatihan dasar kemiliteran secara wajib, pengabdian sebagai prajurit Tentara Nasional Indonesia secara sukarela atau secara wajib, dan engabdian sesuai dengan profesi. Selanjutnya yaitu disebutkan dalam Pasal 6 ayat (4) yang menyatakan bahwa kewajiban warga negara dalam usaha bela negara 
meliputi kewajiban yang diberlakukan kepada warga negara yang menjadi prajurit Tentara Nasional Indonesia sebagai alat pertahanan negara, dan kewajiban yang diberlakukan kepada warga negara sebagai anggota komponen cadangan yang di mobilisasi dalam menghadapi ancaman militer dan ancaman hibrida.

\section{Asas Manfaat}

Asas ini bermakna bahwa segala usaha dalam menyelenggarakan Pertahanan Negara yang memberikan manfaat sebesar-besarnya untuk pembangunan Pertahanan Negara dan kesejahteraan rakyat. Pembangunan kekuatan pertahanan harus dual benefit atau manfaat ganda. Selain itu, Pembangunan pertahanan dan kesejahteraan tidak bisa berjalan satu persatu, melainkan harus berjalan bersamaan. Pertahanan tersebut tidak mungkin dipersiapkan tanpa sokongan kesejahteraan dan sebaliknya. Asas ini terimplementasi dalam beberapa pasal, yaitu Pasal 36, Pasal 37 ayat (1) dan (2). Pasal 36 mengatur bahwa calon komponen cadangan selama mengikuti pelatihan dasar kemiliteran berhak memperoleh uang saku, perlengkapan perseorangan lapangan, rawatan Kesehatan, serta pelindungan jaminan kecelakaan kerja dan jaminan kematian. Pasal 37 ayat (1) menyatakan bahwa calon komponen cadangan yang berasal dari unsur aparatur sipil negara dan pekerja/buruh selama menjalani pelatihan dasar kemiliteran sebagai calon komponen cadangan tetap memperoleh hak ketenagakerjaannya dan tidak menyebabkan putusnya hubungan kerja dengan instansi atau perusahaan tempatnya bekerja. Sementara Pasal 37 ayat (2) menyebutkan bahwa calon komponen cadangan yang berstatus mahasiswa selama menjalani pelatihan dasar kemiliteran sebagai calon komponen cadangan tetap memperoleh hak akademisnya dan tidak menyebabkan kehilangan status sebagai peserta didik.

\section{Asas Legalitas}

Asas legalitas berarti bahwa pengelolaan sumber daya nasional serta sarana dan prasarana nasional untuk pertahanan negara dilaksanakan berdasarkan ketentuan peraturan perundang-undangan. Asas ini yang pengaturannya terkandung dalam beberapa pasal, yaitu pertama, Pasal 11 ayat (3) yang menyebutkan ketentuan lebih lanjut mengenai peyelenggaraan pembinaan kesadaran bela negara diatur dengan peraturan pemerintah, kedua, Pasal 12 ayat (3) yang menyatakan ketentuan lebih lanjut mengenai kebijakan pembinaan bela negara diatur dengan pertauran presiden. Ketiga, Pasal 13 ayat (3) yang menyebutkan pelatihan dasar kemiliteran secara wajib dilaksanakan sesuai dengan ketentuan mengenai pembentukan komponen cadangan yang diatur 
dalam undang-undang ini, keempat, Pasal 14 yang menyatakan pengabdian sebagai prajurit tentara nasional Indonesia secara sukarela sebagaimana sesuai dengan ketentuan peraturan perundang-undangan. Kelima. Pasal 16 ayat (3) yang mengatur bahwa ketentuan lebih lanjut mengenai pembinaan dan kerja sama dalam pelaksanaan pengabdian sesuai dengan profesi diatur dengan peraturan pemerintah, dan terakhir, Pasal 24 yang menyebutkan ketentuan lebih lanjut mengenai penataan komponen pendukung diatur dengan peraturan pemerintah.

\section{Asas Selektivitas}

Asas ini mengandung makna bahwa tidak setiap tingkat keadaan bahaya memerlukan pengerahan kekuatan pertahanan negara secara total. Sistem pertahanan rakyat semesta menggunakan pendekatan pembinaan kekuatan pertahanan yang kenyal. Mobilisasi terhadap berbagai potensi kekuatan pertahanan negara dilaksanakan secara selektif, dengan mendahulukan yang paling siap dan paling tepat untuk dikembangkan menjadi bagian kekuatan operasional pertahanan keamanan negara.

Negara berhak menentukan prioritas dalam menyiapkan sumber daya untuk pertahanan, begitu pula dengan penentuan mobilisasi dan demobilisasi. Pengaturan harus jelas bahwa mobilisasi dan demobolisasi harus diawali dengan pernyataan keadaan yang dianalisis dengan cermat berdasarkan eskalasi dan spektrum ancaman oleh lembaga yang memang memiliki otoritas tepat. Dalam pergaulan peradaban internasional biasanya dalam sebuah negara ada sebuah dewan yang memberikan pertimbangan terkait keamanan nasional kepada Presiden (the best assessment in national security).

Asas selektivitas ini termuat dalam beberapa pasal yaitu, pertama, Pasal 11 ayat (3) yang mengatur bahwa pengabdian sesuai dengan profesi untuk menghadapi ancaman militer dan ancaman hibrida dilakukan melalui keanggotaan komponen cadangan dan/atau komponen pendukung, kedua, Pasal 29 yang menyebutkan komponen cadangan disiapkan untuk kerahkan melalui mobilisasi guna memperbesar dan memperkuat kekuatan dan kemampuan komponen utama dalam menghadapi ancaman militer dan ancaman hibrida. Ketiga, Pasal 61 ayat (2) yang mengatur penggunaan komponen cadangan berada di bawah komando dan kendali panglima tentara Indonesia, dan keempat, Pasal 65 yang menyebutkan komponen pendukung yang tidak ditingkatkan statusnya menjadi komponen cadangan wajib memberikan dukungan pada saat mobilisasi yang dikoordinasikan oleh kementrian/lembaga sesuai dengan tugas dan fungsi. 


\section{Asas Efektivitas}

Asas ini berarti bahwa pengembangan kekuatan pertahanan keamanan negara harus dijamin efektif dimana penambahan kekuatan dilakukan melalui mekanisme mobilisasi dan penyusutan kekuatan melalui mekanisme demobilisasi, baik dalam ragam, jumlah maupun mutu. Keefektifan tersebut sangat penting dalam membangun kekuatan. Penyiapan komponen pendukung, pembentukan komponen cadangan serta pembinaan kesadaran bela negara merupakan langkah strategis untuk mencapai keefektifan. Meningkatkan kualitas sumber daya manusia agar berdisiplin dan memiliki jiwa militansi serta patriotis perlu sarana yang tepat agar bermanfaat bagi penguatan negara.

Asas efektivitas ini terkandung dalam muatan beberapa pasal yaitu Pasal 25 ayat (1) yang menyatakan pembinaan komponen pendukung merupakan kegiatan peningkatan kualitas dan/atau kuantitas komponen pendukung dalam usaha pertahanan negara, Pasal 26 ayat (1) yang mengatur bahwa pembinaan komponen pendukung melalui kegiatan sosialisasi, bimbingan teknis dan/ atau simulasi, dan Pasal 57 ayat (1) yang menyebutkan bahwa pembinaan komponen cadangan merupakan kegiatan yang bertujuan untuk meningkatkan kualitas, nilai guna, dan daya guna untuk kepentingan pertahanan negara.

\section{Asas Efisiensi}

Makna asas ini yaitu pengerahan kekuatan harus disesuaikan dengan ancaman. Seluruh komponen bangsa adalah sumber daya yang bisa dikerahkan kapan saja berdasarkan kebutuhan. Negara tidak boleh tersandera dimana ketika negara membutuhkan sumber daya tertentu ternyata tidak bisa dikerahkan karena aturan yang tidak berbasis kepada efesiensi. Komponen cadangan dan komponen pendukung harus dapat dikerahkan untuk menanggulangi berbagai ancaman sesuai dengan eskalasi dan spectrum. Hal yang harus diperhatikan adalah mekanisme mobilisasi yang harus jelas.

Asas efesiensi ini dapat dilihat dalam beberaoa pasal yaitu Pasal 64 ayat (2) yang menyatakan komponen pendukung yang dikenai mobilisasi harus ditingkatkan statusnya menjadi komponen cadangan, Pasal 65 ayat (1) yang menyaebutkan komponen pendukung yang tidak ditingkatkan statusnya menjadi komponen cadangan wajib memberikan dukungan pada saat mobilisasi yang dikoordinasikan oleh kementrian/lembaga sesuai dengan tugas dan fungsi, dan Pasal 66 ayat (1) yang mengatur bahwa komponen cadangan yang berasal dari unsur warga negara wajib memenuhi penggilan untuk mobilisasi. 


\section{Asas Proporsionalitas}

Makna asas ini adalah pengelolaan sumber daya nasional serta sarana dan prasarana nasional yang dilaksanakan secara proporsional sesuai dengan eskalasi dan spektrum ancaman yang dihadapi. Asas proposionalitas ini termuat dalam Pasal 3 yang menyatakan pengelolaan sumber daya nasional untuk pertahanan negara bertujuan untuk mentransformasikan sumber daya manusia, sumber daya alam, dan sumber daya buatan, serta sarana dan prasarana nasional menjadi kekuatan pertahanan negara yang siap digunakan untuk kepentingan pertahanan negara. Asas ini juga termuat dalam Pasal 4 ayat (1) yang mengatur bahwa pengelolaan sumber daya nasional untuk pertahanan negara dipersiapkan secara dini untuk menghadapi ancaman. Makna ancaman tersebut diatur dalam ayat (2) pasal tersebut yang menyebutkan bahwa ancaman tersebut terdiri atas ancaman militer, ancaman nonmiliter, dan/ atau ancaman hibrida. Selain itu, ayat (3) pasal tersebut menyebutkan jenis-jenis ancaman tersebutdapat berwujud agresi, terorisme, komunisme, separatisme, pemberontakan bersenjata, bencana alam, kerusakan lingkungan, pelanggaran wilayah perbatasan, perompakan dan pencurian sumber daya alam, wabah penyakit, peredaran dan penyalahgunaan narkoba, serangan siber, serangan nuklir, serangan biologi, serangan kimia, atau ancaman yang membahayakan kedaulatan neagara.

\section{Implikasi Undang-Undang Nomor 23 Tahun 2019 tentang Pengelolaan Sumber Daya Nasional untuk Pertahanan Negara Terhadap Rakyat}

\section{Hak Asasi Manusia}

Bela negara dalam konsepsi UU a quo dilakukan atas dasar sukarela warga negara dan dilaksanakan atas dasar kesadaran warga negara serta keyakinan pada kekuatan sendiri yang ditumbuhkembangkan melalui usaha Bela Negara. Namun demikian, kegiatan mobilisasi sebagai komponen cadangan ini tidak seharusnya diwajibkan karena dapat melanggar ketentuan-ketentuan internasional. Terkait hal ini, Amnesty Internasional pada 1997 menyatakan bahwa hak untuk menolak dinas militer atas dasar hati nurani bukanlah masalah kecil di luar arus utama perlindungan dan promosi hak asasi manusia internasional.

Pasal 66 UU a quo mengatur kewajiban bagi warga negara yang tergabung dalam komponen cadangan memenuhi panggilan untuk mobilisasi. ${ }^{13} \mathrm{UU}$ a quo juga menggunakan ancaman pidana bagi warga negara yang tidak ikut serta

13 Pasal 66 ayat (1) menyatakan bahwa komponen cadangan yang berasal dari unsur warga negara wajib memenuhi panggilan untuk mobilisasi, sedangkan ayat (2) menyebutkan bahwa setiap pemilik dan/atau pengelola sumber daya alam, sumber daya buatan, serta sarana dan prasarana nasional yang ditetapkan statusnya sebagai komponen cadangan wajib menyerahkan pemanfaatannya untuk kepentingan mobilisasi. D. S. N. Heriyanto, "Legal Challenges to Improve and Reform the Privatized Water Services in Indonesia", 1 (1) Public Goods \& Governance 11, 2016, hlm. 12-14. 
dalam mobilisasi komponen cadangan ini. Seharusnya, apabila sudah ditentukan secara sukarela maka tidak ada ancaman pidana terhadap pemenuhan mobilisasi tersebut. Ancaman pidana tersebut diatur dalam Pasal 77 ayat (1), yaitu berupa pidana penjara paling lama 4 tahun, sedangkan ayat (2) pasal tersebut mengatur ancaman pidana berupa pidana penjara paling lama 2 tahun.

Pasal 79 ayat (1) UU a quo juga mengatur ancaman pidana bagi warga negara yang tidak berkenan menyerahkan sumber daya yang dimiliki untuk ditetapkan sebagai komponen cadangan dengan pidana penjara paling lama 4 tahun. Ayat (2) pasal tersebut juga mengatur ancamana pidana bagi seseorang yang melakukan tipu muslihat berkenaan dengan menghalang-halangi penetapan sumber daya nasional untuk pertahanan negara dengan pidana penjara paling lama 4 tahun.

Ketentuan-ketentuan dalam pasal tersebut melanggar ketentuan Hak Asasi Manusia yang diatur dalam Pasal 28I UUD NRI 1945 serta resolusi PBB terkait dengan prinsip consicentious objection yang mengakui bahwa setiap warga negara yang atas dasar keyakinan dan agamanya berhak menolak dalam wajib militer karena menolak penyelesaian konflik dengan senjata. Komisi Tinggi HAM PBB juga telah mengeluarkan resolusi mengenai penolakan terhadap wajib militer oleh seseorang melalui Resolusi 1998/77 yang menyatakan bahwa negara-negara harus menahan diri dari menundukkan para penentang yang berhati nurani untuk hukuman berulang karena kegagalan untuk melakukan dinas militer. Resolusi tersebut juga mendorong negara-negara untuk mempertimbangkan pemberian suaka kepada orang-orang yang menolak wajib militer atas dasar hati nurani karena mereka takut penganiayaan karena penolakan mereka untuk melakukan dinas militer.

\section{Kriminalisasi}

Muladi $^{14}$ menyatakan bahwa ada beberapa ukuran yang secara doktrinal harus diperhatikan sebagai pedoman terkait permasalahan kriminalisasi, yaitu kriminalisasi tidak boleh terkesan menimbulkan overkriminalisasi yang masuk kategori the misuse of criminal sanction; kriminalisasi tidak boleh bersifat ad hoc; kriminalisasi harus mengandung unsur korban victimizing, baik aktual maupun potensial; kriminalisasi harus memperhitungkan analisa biaya, hasil, dan prinsip ultimum remedium; kriminalisasi harus menghasilkan peraturan yang enforceable; kriminalisasi harus mampu memperoleh dukungan publik; kriminalisasi harus mengandung unsur subsosialitet mengakibatkan bahaya bagi masyarakat, 256.

${ }_{14}$ Muladi, Kapita Selekta Hukum Pidana, Badan Penerbit Universitas Diponegoro, Semarang, 1995, hlm. 
sekalipun kecil sekali; dan kriminalisasi harus memperhatikan peringatan bahwa setiap peraturan pidana membatasi kebebasan rakyat dan memberikan kemungkinan kepada aparat penegak hukum untuk mengekang kebebasan itu.

Kriminalisasi terhadap perbuatan "tidak memenuhi panggilan mobilisasi" cenderung menimbulkan overkriminalisasi mengingat ketentuan hukum atas sikap anggota komponen cadangan yang tidak memenuhi panggilan mobilisasi seharusnya tidak diatur dengan mekanisme pemidanaan, karena tidak relevan dan cenderung kontraproduktif. Sebagaimana telah dijelaskan sebelumnya, dari aspek HAM ketentuan ini justru bertentangan dengan spirit kemerdekaan setiap orang untuk berhati nurani, berfikir, bersikap yang dijamin oleh HAM. Jadi, sebaiknya pendekatan hukum yang digunakan bukan melalui sanksi pidana tetapi dengan mekanisme sanksi administrative karena kegiatan pendaftaran dan proses dalam pembentukan komponen cadangan lebih bernuansa administratif.

Hal tersebut juga berlaku pada ketentuan pemidanaan terhadap sikap warga negara yang tidak menyerahkan pemanfaatan sebagian atau seluruh sumber daya alam, sumber daya buatan, dan/atau sarana dan prasarana nasional miliknya yang telah ditetapkan menjadi komponen cadangan untuk digunakan dalam mobilisasi. Selaku pemilik, warga negara yang bersangkutan bisa saja menolak menyerahkan kepemilikannya, dengan alasan tertentu, misalnya, pihak yang bersangkutan tidak berkenan dengan kebijakan mobilisasi yang ditetapkan oleh pemerintah, karena diduga hanya untuk kepentingan politik mempertahankan kekuasaan semata. Sikap warga negara karena alasan sikap atau pandangan politik yang berbeda tentu tidak tepat diatasi dengan sanksi pemidanaan.

\section{Potensi Memicu Konflik Vertikal}

Penggunaan komponen cadangan, terutama pada wilayah penggunaan sumber daya manusia, dianggap sudah tidak relevan dengan menjadikan masyarakat sipil sebagai kekuatan pendukung dalam konteks pelatihan secara militer. Karena kondisinya sudah berbeda, jika dulu bangsa Indonesia dalam merebut kemerdekaan dari tangan penjajah masih menggunakan cara-cara konvensional yaitu semua rakyat Indonesia harus ikut angkat senjata dalam melakukan perlawanan terhadap para penjajah. Hal itu disebabkan Indonesia tidak memiliki sistem pertahanan yang jelas, sehingga sistem pertahanannya melibatkan sebagai kekuatan utama.

Pada masa sekarang ini, perang tidak lagi dengan menggunakan fisik tetapi lebih kepada teknologi. Oleh karena itu, UU PSDN ini justru dapat berpotensi disalahgunakan oleh kekuasaan, terutama pada tingkatan wilayah politik praktis sehingga akan menimbulkan konflik secara vartikal antara penguasa dengan rakyat. Secara jelas bahwa watak negara adalah cenderung represif, yang mana 
menurut Bakunin negara merupakan alat bagi siapa saja yang berkuasa untuk melakukan penindasan dan penghisapan terhadap sesama manusia. ${ }^{15} \mathrm{Hal}$ ini dikarenakan kekuasaan bukan terletak pada individu tetapi terletak pada sistem.

Kekhawatiran akan disalahgunakan oleh kekuasaan itu timbul karena adanya penggunakan mobiliasi yang ada di Pasal 63, yang mengatur bahwa dalam hal seluruh atau sebagian wilayah negara kesatuan republik Indonesia dalam keadaan darurat militer atau keadaan perang presiden dapat menyatakan mobilisasi. Ketidakjelasan makna dari darurat militer tersebut yang tidak memiliki tolak ukur yang jelas, sehingga dapat ditafsirkan secara serampangan oleh penguasa. Selain itu, apabila berkaca pada rezim Soeharto yang berkuasa selama 32 tahun dimana terjadi penggunaan kekuasaan dengan menjadikan militer sebagai alat untuk menakhlukkan lawan-lawan politiknya serta orangorang yang dianggap berbahaya bagi kekuasaannya. Artinya, pasal seperti ini bisa saja digunakan, seperti yang terjadi pada peristiwa 1998 yaitu penggunaan perangkat militer untuk memukul mundur masa aksi yang menuntut keadilan kepada pengusa. Oleh karenanya menjadi penting pengaturan secara jelas untuk penggunaan mobilisasi oleh kekuasaan, sehingga apa yang terjadi di masalalu tidak terulang kembali.

\section{Pengaruh Pendanaan dari Non APBN/APBD}

Ketentuan pendanaan atau anggaran dalam Undang-undang tentang Pengelolaan Sumber Daya Nasional untuk Pertahanan Negara (UU PSDN) berpotensi bertentangan dengan prinsip sentralisme pengelolaan anggaran pertahanan. UU PSDN mengatur bahwa pendanaan yang diperlukan untuk pengelolaan sumber daya nasional untuk pertahanan negara tidak hanya berasal dari APBN. Selanjutnya Pasal 75 UU PSDN menjelaskan pendanaan Pengelolaan Sumber Daya Nasional untuk Pertahanan Negara bersumber dari APBN, APBD, dan sumber pendanaan lain yang sah dan tidak mengikat yang diatur dengan peraturan perundang-undangan. Sedangkan Pasal 25 Undang-Undang Nomor 3 Tahun 2002 tentang Pertahanan Negara menyatakan pertahanan negara dibiayai dari Anggaran Pendapatan dan Belanja Negara (APBN).

Pembiayaan sektor pertahanan negara yang berasal dari luar APBN dapat menimbulkan masalah mengingat penggunaan anggaran berpotensi sulit dikontrol dan tidak menutup kemungkinan munculnya praktik penyalahgunaan anggaran. Namun di sisi lain, pendanaan ini justru membuka peluang pihakpihak yang berkepentingan memanfaatkan kekuatan komponen pertahanan

Moh. Kusnardi dan Bintan R. Saragih, Ilmu Negara, Cetakan Kelima, Gaya Media Pratama, Jakarta, 2005, hlm. 27. 
negara dengan ikut serta memberikan pendanaan, isalnya, perusahaan swasta guna melindungi kepentingan bisnisnya, ikut serta menyukseskan pendidikan bela negara, dengan maksud agar warga negara di wilayah usahanya dapat melindungi kepentingan bisnisnya.

\section{Penutup}

Berdasarkan hasil kajian dan pembahasan politik hukum UU a quo di atas, dapat disimpulkan bahwa UU a quo dilatarbelakangi oleh suatu keadaan untuk memperkuat pertahanan negara dalam menghadapi ancaman melalui sistem pertahanan rakyat semesta. Penguatan pertahanan negara ini dilakukan melalui pengelolaan sumber daya nasional, yang dilaksanakan melalui usaha bela negara, penataan komponen pendukung, pembentukan komponen cadangan, penguatan komponen utama, serta mobilisasi dan demobilisasi.

Hasil penelitian juga menunjukkan bahwa arah politik hukum UU a quo ialah mewujudkan tegaknya kedaulatan negara, terjaganya keutuhan wilayah, dan keselamatan segenap bangsa dari segala bentuk ancaman. Oleh karena itu, dalam mencapai tujuan tersebut, fungsi pertahanan negara diselenggarakan dengan memanfaatkan seluruh potensi sumber daya nasional serta sarana dan prasarana nasional sebagai bagian penting dari komponen pertahanan negara sekaligus digunakan untuk kesejahteraan rakyat. Selain itu, sejumlah asas yang tercantum sebagai dasar dalam UU a quo cukup termanifestasi dalam beberapa pasal. Namun demikian, asas-asas ini kemudian tereduksi oleh kecenderungan materi muatan UU a quo yang bernuansa melanggar hak asasi manusia, overkriminalisasi, kurang akomodatif terhadap kondisi ancaman kekinian, serta potensi penyalahgunaan dalam pendanaannya. Untuk menghindari adanya konflik antara negara dengan rakyat (konflik vartikal), perlu ada tafsiran dan tolak ukur yang jelas tentang darurat militer sehingga penggunaan mobilisasi komponen cadangan tidak digunakan secara serampangan oleh penguasa, yang justru merugikan rakyat itu sendiri.

\section{Daftar Pustaka}

\section{Buku}

Ali, Zainuddin, Metode Penelitian Hukum, Cetakan Kelima, Sinar Grafika, Jakarta, 2014.

Irianto, Sulistyowati dan Shidarta, Metode Penelitian Hukum: Konstelasi dan Refleksi, Cetakan Pertama, Yayasan Obor Indonesia, Jakarta, 2009.

Kusnardi, Moh dan Bintan R. Saragih, Ilmu Negara, Cetakan Kelima, Gaya Media Pratama, Jakarta, 2005. 
Mahfud MD, Moh, Politik Hukum di Indoensia, Cetakan Ketujuh, Rajawali Pers, Jakarta, 2017.

Muladi, Kapita Selekta Hukum Pidana, Badan Penerbit Universitas Diponegoro, Semarang, 1995.

Sungguno, Bambang, Metode Penelitian Hukum, Raja Grafindo Persada, Jakarta, 2003.

\section{Jurnal}

Gumanti, Retna, "Reconceptualizing Consumer Contracts in the Philosophical Perspective of Pancasila", 1 (1) Prophetic Law Review 37, 2019.

Heriyanto, D. S. N., "Legal Challenges to Improve and Reform the Privatized Water Services in Indonesia", 1 (1) Public Goods \& Governance 11, 2016.

Mardhani, Dewie, et.al., "Keamanan dan Pertahanan Dalam Studi Ketahanan Nasional Guna Mewujudkan Sistem Keamanan Nasional", Jurnal Pertahanan \& Bela Negara, Vol. 10 No. 3, Desember 2020.

Maujana Saragih, Hendra, "Diplomasi Pertahanan Indonesia Dalam Konflik Laut China Selatan", Jurnal Ilmu Politik dan Komunikasi, Vol. 7 No. 1, Juni 2018.

\section{Internet}

"Risalah Rapat Komisi I DPR RI pada Rabu 21 Agustus 2019", http://www.dpr.go.id/uu/detail/id/44, diakses pada tanggal 20 Maret 2021.

"Naskah Akademik Rancangan Undang-Undang tentang Pengelolaan Sumber Daya Nasional untuk Pertahanan Negara", https://www.bphn.go.id/data/document/na ruu tentang pengelolaan sumber daya nasional untuk pertahanan negara.pdf, diakses pada 23 Maret 2021.

\section{Peraturan Perundang-Undangan}

Undang-Undang Dasar Negara Republik Indonesia Tahun 1945.

Undang-Undang Nomor 23 Tahun 2019 tentang Pengelolaan Sumber Daya Nasional untuk Pertahanan Negara. Tambahan Lembaran Negara RI Nomor 6413. 